the self. ${ }^{10}$ The investigation of out of body experiences and related mechanisms at the temporo-parietal junction might thus allow us to improve our neuroscientific models of self and corporeal awareness. Although many other cortical areas are involved in self processing, recent neuroimaging studies indicate a key role for the temporo-parietal junction. This is not only true for out of body experiences but also for many aspects of body and self processing, such as the integration of multisensory bodily information, the visual perception of the body, the perception of biological motion, and the distinction between self and other. ${ }^{311} 12$

The experimental investigations of these multisensory and cognitive mechanisms in out of body experiences and related illusions, in combination with neuroimaging and behavioural techniques, will further our understanding of the central mechanisms of self and corporeal awareness-much as previous research was successful with respect to understanding the central mechanisms of phantom limbs. ${ }^{9}$
Olaf Blanke professor

Laboratory of Cognitive Neuroscience, Ecole Polytechnique Fédérale de Lausanne, CH-1015 Lausanne, Switzerland (olaf.blanke@epfl.ch)

Competing interests: None declared.

1 Irwin HJ. Flight of mind: A psychological study of the out-of-body experience. Metuchen, NJ: Scarecrow Press, 1985.

Blackmore SJ. Beyond the body. An investigation of out-of-body experiences. London: Heinemann, 1982.

Blanke O, Landis T, Spinelli L, Seeck M. Out-of-body experience and autoscopy of neurological origin. Brain 2004;127:243-58.

Neisser U. The five kinds of self-knowledge. Phil Psychol 1988;1:35-59.

Metzinger T. Being no one. Cambridge, MS: MIT Press, 2003.

Devinsky O, Feldmann E, Burrowes K, Bromfield E. Autoscopic phenomDevinsky O, Feldmann E, Burrowes K, Bromfiel
ena with seizures. Arch Neurol 1989:46:1080-8.

7 Brugger P, Regard M, Landis T. Illusory reduplication of one's own body:phenomenology and classification of autoscopic phenomena. Cogn Neuropsychiatr 1997;2:19-38.

8 Blanke O, Ortigue S, Landis T, Seeck M. Stimulating illusory own-body perceptions. Nature 2002;419:269-70.

9 Ramachandran VS, Hirstein W. The perception of phantom limbs. Brain 1998;121:1603-30.

10 Kircher T, David A. The self in neuroscience and psychiatry. Cambridge: Cambridge University Press, 2003.

11 Decety J, Sommerville JA. Shared representations between self and other: a social cognitive neuroscience view. Trends Cogn Sci 2003;7:527-33.

12 Blanke O, Arzy S. The out-of body experience. Disturbed self processing at the temporo-parietal junction. Neuroscientist (in press).
at

\title{
Treatment of homosexuality during apartheid
}

\section{More investigation is needed into the shameful way homosexuality was treated}

Homosexuality is assuredly no advantage, but it is nothing to be ashamed of, no vice, no degradation, it cannot be classified as an illness; we consider it to be a variation of the sexual function, produced by a certain arrest of the sexual development. It is a great injustice to persecute homosexuality as a crime--and a cruelty too. ${ }^{1}$

Sigmund Freud

$\mathrm{I}$ $\mathrm{n}$ the 20th century, doctors were repeatedly accomplices in state repression, brutality, and genocide. The most notorious examples of medical complicity in state abuse are the Nazi doctors who participated in genocide and the Japanese doctors who practised biological warfare. ${ }^{2}$ Included among the former were psychiatrists, who in carrying out Hitler's euthanasia programme on their patients seem to have been in a state of complete moral disarray.

Involvement of psychiatrists in state repression has if anything escalated since 1945, the most extensive example being the use of psychiatric treatment for suppression of dissenters in the Soviet Union. Similar practices arose in other east European states, China, and Cuba. Recently there have been claims of psychiatric abuse of detainees at Guantánamo Bay. ${ }^{3}$

During the apartheid years in South Africa, medical personnel were involved in abuse of prisoners, ${ }^{4}$ the most well-known case being the death in custody of Steve Biko. ${ }^{5}$ From 1969 to 1987, psychiatrists of the South African Defence Force were implicated in serious abuses, stemming from attempts to cure homosexual conscripts. ${ }^{6}$ The South African Defence Force regarded homosexuality as subversive, and severe penalties were prescribed, although attitudes were often inconsistent.

The long history of medical treatment to convert homosexuals to heterosexuals reached a peak in the seventies. The results were unconvincing, if not hopeless, and experience showed that neither patients the definition of homosexuality as an illness from the American Psychiatric Association's Diagnostic and Statistical Manual of Mental Disorders in 1973, ${ }^{9}$ interest in treatment faded and it would be thought the matter was of interest only to historians.

These developments had little influence on psychiatrists in the South African Defence Force. Militarisation of the white population escalated after the establishment of universal conscription in 1967. Conscript ranks were screened for homosexuals by doctors and chaplains. Threatened with punishment if they did not comply, they were admitted to the secretive Ward 22 at 1 Military Hospital, Voortrekkerhoogte, Pretoria. In later years, homosexual women were also selected.

Subjects were first given crude behaviour therapy. This consisted of exposure to black and white pictures of naked men while receiving electric shocks, then viewing Playboy magazine centrefolds. The shock was so intense that in one case the subject's shoes flew off. ${ }^{10}$

Homosexuals were indiscriminately grouped in the psychiatric ward with drug abusers, conscientious objectors, the politically unreliable, and the seriously mentally ill. They were often subjected to narcoanalysis, showing an ominous similarity to psychiatric re-education in the Soviet Union. Others were chemically castrated with massive doses of hormones. Drug addicts were threatened with transport to remote Greefswald (later Magaliesoord), regarded as little less than a forced labour camp.

Accounts exist of suicide during treatment and after discharge. The most well known is Jean Erasmus, who killed himself after providing detailed information about the programme.

The next stage in treatment went beyond any justifiable basis. Recurrent allegations have been made that between 1969 and 1987 approximately 900 men and 
women had gender reassignment surgery, the only known example of such operations being performed in military hospitals. ${ }^{10}{ }^{11}$ They were given new identity documents, discharged from the military, and told to cut themselves off from family and friends.

The casualty rates were high. Patients died during surgery, and some were discharged before reassignment was completed, with extra surgery required. Preoperative or postoperative assessment was not done, informed consent was not obtained, and expensive hormone regimens were needed to maintain appearance. Patients later petitioned the military for compensation to pay for hormones or surgery.

The rationale for giving homosexuals reassignment surgery, in complete ignorance of the scientific literature on transsexualism, can only be described as repulsive. It was based on the simplistic belief that male homosexuals were sissies, female homosexuals were tomboys, and surgery would end their preference for the same sex by allowing them to fulfil their projected role in the opposite sex. The only conclusion that can be reached is that the psychiatrists involved were not only woefully and balefully ignorant but functioned as an extension of the military ethos.

Rumours of these activities circulated for years, ${ }^{12}$ but details of the programme first came to light at hearings of the Truth and Reconciliation Commission with submission of The Aversion Project, a detailed investigation of treatment of homosexuals in the South African Defence Force by a coalition of groups, including the Medical Research Council. ${ }^{13}$

In 1995, the Medical Association of South Africa issued a public apology for past wrongdoings. ${ }^{14}$ The South African Society of Psychiatrists does not concede that major abuses were perpetuated from within its ranks. ${ }^{15}$ Until there is a full and open investigation of medical abuses in the South African Defence Force, psychiatry in South Africa will remain compromised. To maintain credibility, offenders must be brought to justice and a regulatory system established to ensure such atrocities do not occur again. Anything less will be a serious injustice.

Robert M Kaplan forensic psychiatrist

Liaison Clinic, 310 Crown Street, Wollongong, New South Wales 2500, Australia

(liaison3@bigpond.com)

Competing interests: None declared.

1 Gay P. Freud, a life in our time. London: Pan Macmillan 1989.

2 Lifton RJ. The Nazi doctors:medical killing and the psychology of genocide. New York: Basic Books, 1986

Lifton RJ. Doctors and torture. N Engl J Med 2004;351:415-6.

4 Human Rights Commission Fact Paper FP7. Deaths in detention. Braamfontein, August 1990.

Silove D. Doctors and the state: lessons from the Biko case. Soc Sci Med Silove D. Doctors
1990;30:417-29.

1990;30:417-29.
Kaplan R. The aversion project-psychiatric abuses in the South African defence force during the apartheid era. S Afr Med J 2001;90:216-7.

7 Smith G, Bartlett A, King M. Treatments of homosexuality in Britain since the 1950s - an oral history: the experience of patients. BMJ 2004;328:427.

8 King M, Smith G, Bartlett A. Treatments of homosexuality in Britain since the $1950 \mathrm{~s}-$ an oral history: the experience of professionals. BMJ 2004;328:429

9 Obituary.Judd Marmor. BMJ 2004;328:466.

10 Kirk Paul. Mutilation by the military (and related articles). Mail \& Guardian, August 4-August 10, 2000. www.geocities.com/crosswix/index.html (accessed 10 Dec 2004)

11 Bell T. Unfinished business: South Africa, apartheid and truth. New York: Verso, 2003.

12 Sher A. Beside myself. London: Arrow, 2002.

13 Van Zyl M, de Gruchy J, Lapinsky S, Lewin S, Reid G. The aversion project: human rights abuses of gays and lesbians in the SADF by health workers during the apartheid era. Cape Town: Simply Said and Done on behalf of Gay and Lesbian Archives Health and Human Rights Project, Medical Research Council, National Coalition for Gay and Lesbian Equality, 1999.

14 Van der Linde I. Sometimes having to say you're sorry. S Afr Med J 1995:85:715-6.

15 Gillis LS, Nash ES. Psychiatry under scrutiny-the Society of Psychiatrists in the apartheid years. S Afr J Psychiatry 2002;8:7-11.

\section{Climate change and risk to health}

\section{The risk is complex, and more than a sum of risks due to individual climatic factors}

$\mathrm{L}$ ast century was the warmest for 1800 years. Earth's average surface temperature apparently is now Whigher than for the previous 100000 years. Combinations of long cycle variations in orbital and planetary motion cause changes in the world's climate, as do shorter term irregular variations in solar activity and vulcanism. Extraordinarily, the human enterprise is now so large that we are imposing extra "forcing" on the climate system, via emission of greenhouse gases. ${ }^{12}$

The anticipated change in climate (average global warming of around $2-3^{\circ} \mathrm{C}$ by 2100 ) would be extremely rapid in geological terms ${ }^{12}$-and much faster than the environmentally disruptive warming that began around 15000 years ago, after the last ice age. If we cannot reduce our escalating emission of greenhouse gases radically in the next few decades, climate change will continue for centuries and the oceans will rise for millennia. ${ }^{1}$ Inevitably this would further heighten the risks to population health and survival.

Feedback processes and surprise climate events could amplify these risks greatly. ${ }^{3}$ Advances in climate science and modelled forecasting show that climate change will entail more than linear trends. As the climate system gains energy its variability will increase. Heatwaves, cyclones, floods, and the El Niño cycle will tend to become more frequent and intense. Further, palaeoclimatic evidence, such as that from ice cores and corals, shows that Earth's biogeophysical systems are prone to non-linear and even abrupt changessuch as the collapse of a grounded polar ice sheet and the rapid rise in sea level that then follows.

Research over the past decade has helped clarify the current and future risks to health from climate change. This understanding is incomplete, often uncertain, and sometimes contentious. We are most confident about the direct risks posed by heatwaves (think of the 15000 extra deaths in France in August 2003), cyclones, floods, and increasing air pollution. We expect that biotic systems that are sensitive to climatesuch as bacteria (like salmonella), the complex of vector, pathogen, and host that affects transmission of infection, the production of aeroallergens, and the agro-ecosystems that generate food-will be affected. Some evidence indicates that recent changes in the occurrence of infectious diseases in some locations (tickborne encephalitis in Sweden, cholera outbreaks 